\title{
QUALITY OF RAPESEED OIL AFTER DIFFERENT APPLICATIONS (AMENDMENTS) OF SEWAGE SLUDGE IN SOILS
}

\author{
Najla LASSOUED ${ }^{1,2}$, Essaid BILAL ${ }^{3 *}$ \\ 1 National Agronomic Institute of Tunisia, 1082 Mahragène Tunis, Tunisia; lassoued_najla@yahoo.fr \\ 2 National Institute for Rural Engineering' research, Water and Forestry, BP10, 2080 Ariana, Tunis \\ 3 Ecole Nationale Supérieure des Mines de Saint Etienne, PEG, CNRS UMR 5600, F42023 Saint Etienne France \\ ; ebilal@emse.fr
}

\begin{abstract}
Abstract: Application of sewage sludge rich in organic matter and nutrients such as nitrogen, phosphorus and potassium tend to improve crop yields. Nevertheless, this use is limited because of their heavy metal content. The objective of this work is to study the effect of sewage sludge on the accumulation of metallic trace elements in seeds and rapeseed oil. For this purpose, two different types of sludge by their metal composition were tested. Compared to the control, the supply of industrial sludge increases the metallic load of seeds and rapeseed oil. This increase is noted with the highest doses 50 and $100 \mathrm{t} / \mathrm{ha}$. The same trend was observed during the two years of application. This effect is due to the richness of these slurries in chrome, cadmium and lead. This modification of the metal composition was accompanied by the decrease in the oil content. Analysis of the fatty acid composition of total lipids shows an increase in the percentage of oleic acid at the expense of linoleic and linolenic acids. On the other hand, the increase of 18: 1 at the expense of linoleic and linolenic acids may be the result of metalinduced alteration. For urban sludge, we noticed a variation in $\mathrm{Cr}, \mathrm{Co}, \mathrm{Cu}, \mathrm{Ni}$ and $\mathrm{Zn}$ contents in the seeds depending on the doses. However, for $\mathrm{Cd}$ and $\mathrm{Pb}$ no variation was recorded. An increase in metal trace element levels was well reported at the seed level during the second amendment. We also detected a decrease in oil content with the contribution of industrial sludge. The composition of the total lipids in fatty acids shows an increase in the percentage of oleic acid (C18: 1) at the expense of linoleic (C18: 2) and linolenic (C18: 3) acids under the effect of heavy metals brought by the industrial sludge while no difference is recorded with urban sludge regardless of the dose. No significant differences in heavy metals were observed with the addition of the different doses of urban sludge even after two years of application. Urban sludge has no effect on oil content or fatty acid composition. However, we detected increases in most heavy metals, especially for high doses of industrial sewage sludge.
\end{abstract}

Keywords: Rapeseed Oil, Industrial Sludge, Urban Sludge, linoleic acids, Metallic Trace Elements.

\section{INTRODUCTION}

Rapeseed crop has in recent years a renewed interest in the world for the production of oil, for human consumption and as biofuels besides its use in the feed of cattle in the form of cake. The introduction of rapeseed farming in Tunisia is essentially aimed at increasing the production of oil for human consumption and that of oilseed meal (by-product of rapeseed) rich in proteins sought for animal feed (Ben Salah et al., 2000). Despite the adaptation of this crop and the place it occupies in cereal rotation, it is not well developed in Tunisia. The Pactol variety has been recommended for large-scale cultivation in the north of the country where the rainfall exceeds 400 millimeters per year. Rapeseed is also a model plant for phytoremediation. It is known for its ability to extract and accumulate toxic metals (Marichiol et al., 2004).

In addition to the nutrients, the residual sludge contains heavy metals, which is one of the repelling factors of their agricultural reuse (Adriano, 2001; Alkorta, et al., 2004). The presence of these elements in cultivated soils poses health safety problems because of their possible passage into plants consumed by humans and animals (Ashworth \& Alloway, 2000; Richardset al., 1998).

Numerous studies have tested the accumulative potential of rapeseed (Kchao, et al., 2010; Angelova, et al., 2008; Marichiol, et al., 2004) and its effectiveness on some heavily contaminated surfaces with many physiological and morphological advantages (Salt et al., 1995). It is for this reason that we chose it to study the effect of sewage sludge especially on the chemical composition of the seeds and the quality of the oil. Few studies have been 
undertaken in this direction.

For this purpose, two types of sludge (industrial and urban) different in their composition of metals were tested to highlight the impact of heavy metals present in sewage sludge on certain physiological and biochemical parameters of rapeseeds.

\section{MATERIALS AND METHODS}

\subsection{Culture conditions}

The test device is installed in the open field at the Oued Souhil - Nabeul Agricultural Experiment Station, located about $60 \mathrm{~km}$ from Tunis. For each type of sludge, 4 doses (5, 25, 50 and $100 \mathrm{t} / \mathrm{ha}$ ) were put into play and compared to a control without any input. The trial comprising 9 treatments is conducted in four randomized blocks. The semi rapeseed (Brassica napus L.) Pactol variety was carried out in December with a density of 50 seeds $/ \mathrm{m}^{2}$ and a spacing of $40 \mathrm{~cm}$ from which 13 rows per colza plot were obtained.

The rape crop was conducted in two successive seasons, each time; sewage sludge was applied in the prescribed doses before sowing. However, during the second year, each plot was divided in two, the first part received sludge while the second part received nothing. This division was carried out to study the cumulative effect and the aftereffect of the sludge.

\subsection{Characteristics of the spread sewage sludge}

The chemical analysis of Korba's urban sludge (Table 1) showed that iron and zinc are the most represented elements. The average contents found are organized according to the following sequence: $\mathrm{Fe}>\mathrm{Zn}>\mathrm{Cu}>\mathrm{Cr}>\mathrm{Pb}>$ $\mathrm{Ni}>\mathrm{Co}>\mathrm{Cd}$. As for Bou Bouboub Industrial Sludge's (Table 1), they have very high levels of $\mathrm{Cr}, \mathrm{Pb}$ and $\mathrm{Cd}$. The sequence found is $\mathrm{Cr} \gg \gg \mathrm{Pb}$ $>\mathrm{Zn}>\mathrm{Cd}>\mathrm{Cu}>\mathrm{Ni}>\mathrm{Co}$.

\subsection{Analysis method}

\subsubsection{Oil analysis}

Seed oil extraction is carried out by the Soxhlet method (Harwood, 1984). A sample of milled rapeseeds is placed in a cellulose cartridge in the extractor which is connected on the one hand to a ball cooler and on the other hand to a flask containing 100 $\mathrm{ml}$ of hexane, pumice and a pinch of anhydrous sodium sulfate. The solvent is boiled using a regulated flask heater.

Table 1: Sewage sludge chemical composition (ppm) during the first and second spreading. (The values represent the average of four individual repetitions \pm (SD)). BU: Urban sewage sludge, BI: Industrial sewage sludge.

\begin{tabular}{rrrrr}
\hline & \multicolumn{2}{c}{ Urban sludge (BU) } & \multicolumn{2}{c}{ Industrial sludge (BI) } \\
\hline & \multicolumn{1}{c}{ 1st } & 2nd & \multicolumn{1}{c}{ 1st } & 2nd \\
& spreading & spreading & spreading & spreading \\
\hline $\mathrm{Co}$ & 3.6 & 5.1 & 20.6 & 18.3 \\
$\mathrm{Cd}$ & n.d. & n.d. & 163.0 & 200.8 \\
$\mathrm{Cr}$ & 73.1 & 102.6 & 11387.0 & 13965.0 \\
$\mathrm{Cu}$ & 188.8 & 210.4 & 142.4 & 164.0 \\
$\mathrm{Ni}$ & 19.8 & 17.3 & 61.8 & 63.2 \\
$\mathrm{~Pb}$ & 54.9 & 63.3 & 2854.1 & 3175.9 \\
$\mathrm{Zn}$ & 463.2 & 506.9 & 821.8 & 698.5 \\
\hline
\end{tabular}

The solvent vapors are condensed in the refrigerant and impregnate the sample placed in the cartridge thus extracting the oil. The appropriate time for the extraction used to obtain a better oil yield is 6 hours. The oil content (OC) expressed in $\%$ is given by the following formula: $\%$ oil $=(\mathrm{m} / \mathrm{w}) * 100$

(m: mass of the oil; w: weight of the sample)

Oil yield $(\mathrm{OYH})$ per hectare is determined by multiplying the seed yield (SY) by the oil content (OC)

OYH $(q x / h a)=S Y(q x / h a) *$ OC/100

The analysis of the fatty acids is carried out by gas chromatography after their conversion into more volatile compounds: the methyl esters. For this we use hot methylation using a methanolic solution of sodium methoxide followed by esterification in an acid medium (Cecchi et al., 1985). The methyl esters thus prepared are analyzed by gas chromatography on a capillary column. Fatty acids are identified according to their retention times. Their rate is determined by the ratio between the area of the corresponding peaks and the sum of the peak areas of all the fatty acids (James \& Martin, 1952) according to the formula:

$\%$ Fatty acids $=(\mathrm{S} / \Sigma \mathrm{S}) * 100$

The detection of metal trace elements in the 
oil is determined by the ICP-AES (Inductively coupled plasma atomic emission spectroscopy) technique. A mixture of rapeseed oil and 10\% nitric acid is stirred and then centrifuged at 2800 rpm for 10 minutes. The assay is performed on the lower aqueous layer (Leonardis, et al., 2000).

\subsubsection{Chemical Analysis of Sewage Sludge}

For sewage sludge and soil, the $\mathrm{pH}$ is measured by potentiation in $1 \mathrm{M} \mathrm{KCl}$ after $24 \mathrm{~h}$ in the water/soil ratio of 5. The organic carbon was determined by the method of (Kalra \& Maynard, 1991). Total nitrogen $\left(\mathrm{N}_{\mathrm{t}}\right)$ was determined by the Kjeldahl method. For trace elements, soil and sludge samples were digested with a mixture of $\mathrm{HCl} / \mathrm{HNO}_{3}$ (McGrath \& Cunliffe, 1985) and total concentrations were determined by plasma flash emission spectroscopy (ICP-OES). The apparatus used is of the HORIBA Jobin Yvon type.

\subsubsection{Determination of metallic trace elements in seeds}

The parched seeds were crushed into powder using a porcelain mortar and pestle to obtain a fine powder. Digestion is done hot with aqua regia. Then, the contents of heavy metals were determined by plasma emission spectroscopy (ICP-OES).

\subsubsection{Statistical analysis}

All data were subjected to an analysis of variance. The comparison of the means with the threshold of $5 \%$ of significance was carried out by the Newman-Keuls test using the Statistica 7 software.

Table 2: Variation of seed weight $/ \mathrm{m}^{2}$ and thousand seeds weight at the end of the Rapeseed (Brassica napus L) harvest. The values represent the average of four individual repetitions (SD). T: soil control, TSW: Thousand seeds weight, BU: Urban sewage sludge, BI: Industrial sewage sludge.

\begin{tabular}{ccccccc}
\hline & \multicolumn{2}{c}{ First effect } & \multicolumn{2}{c}{ Cumulative effect } & \multicolumn{2}{c}{ After effect } \\
\cline { 2 - 7 } & $\begin{array}{c}\text { Seeds } \\
\text { weight } / \mathrm{m}^{2}\end{array}$ & WTS & $\begin{array}{c}\text { Seeds } \\
\text { weight } / \mathrm{m}^{2}\end{array}$ & WTS & $\begin{array}{c}\text { Seeds } \\
\text { weight } / \mathrm{m}^{2}\end{array}$ & WTS \\
\hline $\mathrm{T}$ & $48.03 \pm 5.9$ & $2.60 \pm 0.2$ & $45.81 \pm 7.6$ & $2.73 \pm 0.10$ & $52.43 \pm 2.94$ & $2.74 \pm 0.17$ \\
5BU & $81.35 \pm 7.3$ & $2.75 \pm 0.2$ & $42.21 \pm 4.95$ & $2.86 \pm 0.14$ & $43.61 \pm 2.44$ & $2.66 \pm 0.04$ \\
25BU & $116.68 \pm 13.6$ & $2.90 \pm 0.1$ & $55.75 \pm 3.25$ & $2.73 \pm 0.10$ & $53.55 \pm 6.8$ & $2.71 \pm 0.06$ \\
50BU & $121.90 \pm 17.6$ & $2.82 \pm 0.3$ & $62.38 \pm 7.43$ & $2.64 \pm 0.10$ & $81.96 \pm 4.75$ & $2.70 \pm 0.09$ \\
100BU & $117.68 \pm 21.7$ & $2.70 \pm 0.3$ & $98.98 \pm 3.66$ & $2.73 \pm 0.11$ & $92.90 \pm 4.54$ & $2.66 \pm 0.19$ \\
5BI & $64.40 \pm 4.3$ & $2.74 \pm 0.3$ & $43.50 \pm 2.91$ & $2.75 \pm 0.07$ & $57.56 \pm 5.06$ & $2.61 \pm 0.06$ \\
25BI & $80.30 \pm 5.3$ & $2.74 \pm 0.2$ & $54.95 \pm 5.1$ & $2.68 \pm 0.02$ & $62.79 \pm 8.72$ & $2.61 \pm 0.04$ \\
50BI & $107.80 \pm 7.8$ & $2.90 \pm 0.2$ & $67.34 \pm 10.7$ & $2.43 \pm 0.1$ & $75.12 \pm 4.03$ & $2.53 \pm 0.05$ \\
100BI & $108.95 \pm 7.7$ & $2.67 \pm 0.1$ & $59.98 \pm 7.09$ & $1.90 \pm 0.15$ & $80.97 \pm 7.22$ & $2.36 \pm 0.2$ \\
\hline
\end{tabular}

\section{RESULTS}

\subsection{Effect of sewage sludge on rapeseed grain production}

The results obtained during the two test campaigns showed that the sludge used as fertilizer improves the production of rapeseed whatever the type of sludge. The increases observed are all the greater as the sludge dose is higher and the lower production is recorded with the treatment without sludge. However, these increases are less important in the presence of industrial sludge compared to urban sludge or a difference of $39.41 \%$ for the same sludge input $100 \mathrm{t} / \mathrm{ha}$. In addition, the cumulative sludge inflow (2nd spreading) gave less pronounced improvements than those obtained during the $1 \mathrm{st}$ spreading. It is important to note that the increase in grain production is due to an increase in the number of seeds and not to an improvement in the weight of the seed. Indeed, the weight of one 
thousand grains (Table 2) did not undergo any sludge effect in the presence of the 1st application and decreased slightly with the cumulated application. As for the after effect, we note that regardless of the type of mud brought during the previous year, treatments that had previously received sludge gave better yields than those of the control treatment without any input. This is very clear for the 50 and 100t / ha doses. This result can be explained in large part by the mineral-rich soil richness favorable to growth from continuous mineralization of sludge even after stopping spreading. In addition, the sludge supply significantly improved the nitrogen content of the seed (Fig.1). This improvement is more pronounced with the addition of urban sludge and could be related to the essential nutrients provided by the sludge.

\subsection{Effect of sewage sludge on oil content}

The oil content of rapeseed is on average $30 \%$ (Table 4). As for the sludge effect, we notice that for all treatments of the first campaign no noticeable effect was recorded. While during the second season, we detected a decrease in oil content of $11.42 \%$ and $19.65 \%$ with the input of industrial sludge respectively at $50 \mathrm{t} / \mathrm{ha}$ and 100t/ha.

This is essentially related to the decrease in the weight of the seed. As for the oil yield / ha, it follows the evolution of the production with increases on the sludge plots compared to the soil control.

Table 3. Variation of total fatty acid composition (\%) in rapeseed oil treated with different doses and types of sludge during the first and 2 nd spreading. The values are averages of three repetitions.

\begin{tabular}{|c|c|c|c|c|c|c|c|c|c|c|c|}
\hline & & C16:0 & C16:1 & C17:0 & C17:1 & C18:0 & C18:1 & C18:2 & C18:3 & C20:0 & C20:1 \\
\hline \multirow{9}{*}{ 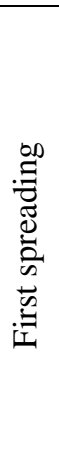 } & $\mathrm{T}$ & 4.74 & 0.27 & 0.040 & 0.07 & 1.91 & 60.57 & 22.15 & 8.40 & 0.69 & 1.12 \\
\hline & $5 \mathrm{BI}$ & 5.15 & 0.32 & 0.042 & 0.08 & 1.69 & 60.63 & 21.38 & 8.87 & 0.66 & 1.15 \\
\hline & 25BI & 5.06 & 0.32 & 0.042 & 0.07 & 1.73 & 60.10 & 21.85 & 8.96 & 0.69 & 1.14 \\
\hline & $50 \mathrm{BI}$ & 4.57 & 0.30 & 0.032 & 0.07 & 1.70 & $69.62^{\mathrm{b}}$ & 15.81 & 5.99 & 0.67 & 1.22 \\
\hline & $100 \mathrm{BI}$ & 5.09 & 0.32 & 0.045 & 0.07 & 1.76 & $72.42^{\mathrm{b}}$ & 12.57 & 5.82 & 0.72 & 1.16 \\
\hline & $5 \mathrm{BU}$ & 4.77 & 0.29 & 0.037 & 0.067 & 1.78 & 61.44 & 21.41 & 8.32 & 0.69 & 1.17 \\
\hline & $25 \mathrm{BU}$ & 5.25 & 0.33 & 0.040 & 0.072 & 1.67 & 59.44 & 22.71 & 8.72 & 0.64 & 1.11 \\
\hline & $50 \mathrm{BU}$ & 4.84 & 0.30 & 0.042 & 0.072 & 1.77 & 59.31 & 23.50 & 8.25 & 0.74 & 1.14 \\
\hline & 100BU & 4.90 & 0.31 & 0.042 & 0.077 & 1.79 & 60.10 & 21.97 & 8.84 & 0.70 & 1.24 \\
\hline \multirow{9}{*}{ 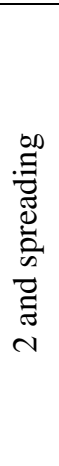 } & $\mathrm{T}$ & 5.13 & 0.26 & 0.05 & 0.08 & 1.85 & $\begin{array}{l}61.28 \\
\end{array}$ & 22 & 6.55 & 0.58 & 1.22 \\
\hline & 5BI & 5.55 & 0.30 & 0.03 & 0.09 & 1.62 & 64.34 & 19.23 & 7.02 & 0.56 & 1.26 \\
\hline & $25 \mathrm{BI}$ & 5.46 & 0.30 & 0.04 & 0.06 & 1.66 & 63.81 & 19.7 & 7.11 & 0.60 & 1.26 \\
\hline & $50 \mathrm{BI}$ & 4.96 & 0.28 & 0.03 & 0.09 & 1.63 & 73.33 & 13.66 & 4.14 & 0.54 & 1.33 \\
\hline & 100BI & 5.48 & 0.30 & 0.05 & 0.08 & 1.69 & 76.13 & 10.42 & 3.97 & 0.61 & 1.28 \\
\hline & $5 \mathrm{BU}$ & 5.16 & 0.27 & 0.04 & 0.08 & 1.72 & 65.15 & 19.26 & 6.47 & 0.57 & 1.28 \\
\hline & $25 \mathrm{BU}$ & 5.64 & 0.31 & 0.05 & 0.07 & 1.60 & 66.15 & 20.56 & 6.87 & 0.52 & 1.23 \\
\hline & $50 \mathrm{BU}$ & 5.23 & 0.28 & 0.04 & 0.07 & 1.71 & 67.02 & 21.35 & 6.4 & 0.64 & 1.26 \\
\hline & $100 \mathrm{BU}$ & 5.30 & 0.29 & 0.05 & 0.07 & 1.72 & 66.81 & 19.82 & 6.99 & 0.60 & 1.36 \\
\hline
\end{tabular}

3.3. Effect of sludge on fatty acid composition in rapeseed oil

Rapeseed oil has a very good fatty acid profile, it consists of a minor fraction of $8 \%$ saturated fatty acids and about $92 \%$ unsaturated fatty acids (fig. 2) including 60\% monounsaturated fatty acids mainly oleic acid (c18: 1), which is also found in peanut, olive and sunflower oils and $32 \%$ poly unsaturated fatty acids: linoleic acid (c18: 2) and linolenic (c18: 3) (Pehlivana et al., 2008 ; Szmigielski et al., 2008).

The analysis of the fatty acid composition of total lipids shows an increase in the percentage of oleic acid (c18: 1) at the expense of linoleic (c18: 2) and linolenic (c18:3) acids under sludge 
effect (Table 3). This increase in c18: 1 may be a consequence of metal-induced alteration of the process of sequential desaturation of 18-carbon fatty acids. For other acids, such as palmitic, palmitoleic, heptadecanoic, heptadecenoic, stearic, arachidic and gadoleic acids, no effects were recorded. Similarly, no difference is recorded with the intake of urban sludge regardless of the dose.
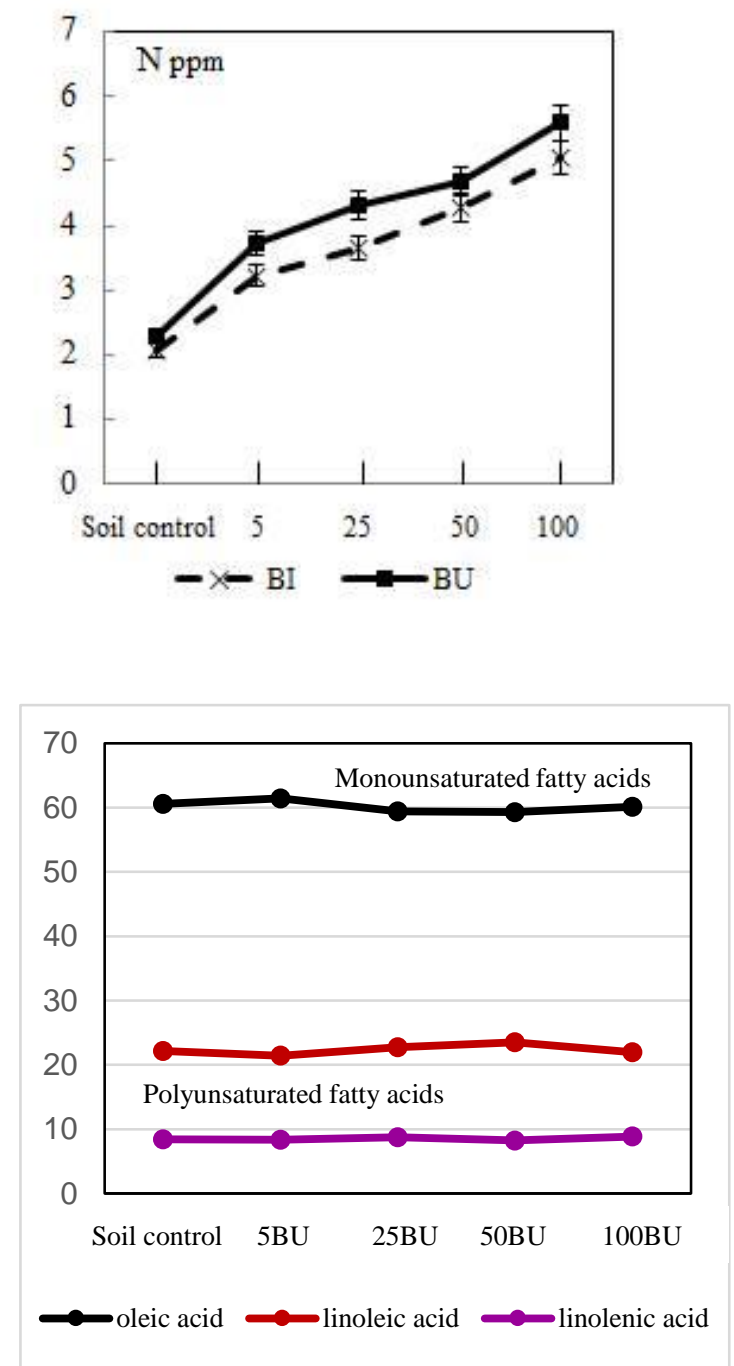

Fig.1: Nitrogen variation content of rapeseeds with increasing sewage sludge doses.

If we compare the composition of total fatty acids for the two companions (table 3 ), we note during the second application a considerable increase in oleic acid at 50t/ha dose. This acid went from $61.28 \%$ (soil control) to $73.33 \%$ (50t/ha bi treatment), an increase of $12 \%$. The content of linoleic and linolenic acids in the oil undergoes a greater decrease under the cumulative effect. The highest dose of industrial sludge $(100 \mathrm{t} / \mathrm{ha})$ resulted in a $52.64 \%$ decrease in linoleic acid and $39.39 \%$ in linolenic acid. These changes in fatty acid composition do not affect the nutritional quality of the oil. The fatty acid composition of total lipids, shows an increase (fig. 2) in the percentage of monounsaturated fatty acids (oleic acid) at the expense of poly-unsaturated fatty acids) in the presence of sludge industrial. The increase of the acid at the expense of linoleic and linolenic acids can be explained by an alteration induced by the metal.

Fig.2 Composition of fatty acids \% in Urban and Industrial sewage sludge.

\subsection{Accumulation of heavy metals in rapeseed}

Regarding the action of sludge on the trace metal content of rapeseed, we noticed that the response of the plant differs according to the type of sludge spread, the amount of sludge added and the year of cultivation. The application of industrial sludge essentially modified the $\mathrm{Cd}$ and $\mathrm{Pb}$ content in the seeds. Thus, we observed an

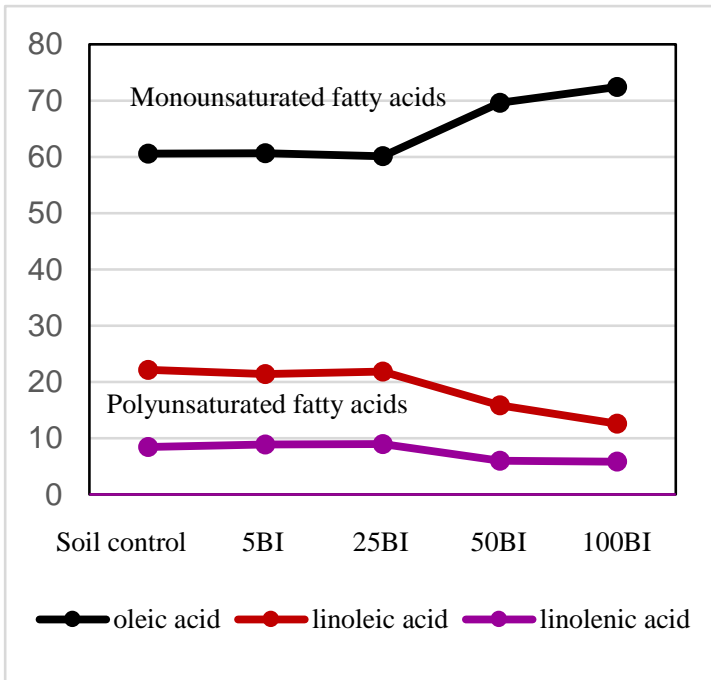

accumulation of $\mathrm{Cd}$ with the addition of $100 \mathrm{t} / \mathrm{ha}$ of sludge during the first year (Fig. 3). This effect was accentuated with the second intake, for which there is an accumulation of $25 \mathrm{t} / \mathrm{ha}$ (50t/ha cumulative). At the 100t/ha rate (200t/ha cumulative), the contents become 4 times higher. The bioavailability of $\mathrm{Cd}$ after cessation of application was also manifested by an accumulation in seeds at 25,50 and $100 \mathrm{t} / \mathrm{ha}$ industrial sludge doses. Similarly, we report that, 
compared to the control, lead levels increase with the addition of 50t/ha of industrial sludge during the first application and the addition of $25 \mathrm{t} / \mathrm{ha}$ of industrial sludge during the second application.

For the other elements, most grades increase with the addition of sludge. This increase becomes sharper following the second sludge supply for $\mathrm{Cr}$, Ni and $\mathrm{Zn}$ contents.

The $\mathrm{Cr}$ content (Fig. 4) increase is clearly visible in the presence of industrial sludge where the levels reach with the highest dose of $10 \mathrm{ppm}$ and $15 \mathrm{ppm}$ for the first and second year of application. This accumulation is less pronounced with urban sludge, a maximum of 6 $\mathrm{ppm}$ is obtained only with the dose of $100 \mathrm{t} / \mathrm{ha}$ following the second campaign. The after effect follows the same evolution as for the first spreading in the case of urban sludge. On the other hand for industrial sludge, the rear effect exceeds that of the 1 st application but remains lower than the cumulative effect.

Table 4: Evolution of oil content and yield (The values represent the average of four individual repetitions $\pm(\mathrm{SD}))$. BU: Urban sewage sludge, BI: Industrial sewage sludge and T: soil control.

\begin{tabular}{lcccc}
\hline & \multicolumn{2}{c}{$\begin{array}{c}\text { Oil Content } \\
(\%)\end{array}$} & \multicolumn{2}{c}{$\begin{array}{c}\text { Oil Yield } \\
(\mathrm{qx} / \mathrm{ha})\end{array}$} \\
\hline Spreading & $1 \mathrm{st}$ & 2nd & $1 \mathrm{st}$ & 2nd \\
\hline $\mathrm{T}$ & $31.28 \pm 0.5$ & $31.62 \pm 0.5$ & 1.502 & 1.449 \\
& & & & \\
5BI & $30.91 \pm 1.2$ & $31.41 \pm 0.5$ & 2.013 & 1.339 \\
25BI & $29.88 \pm 1.6$ & $30.56 \pm 0.9$ & 2.399 & 1.684 \\
50BI & $31.10 \pm 0.4$ & $28.07 \pm 1.6$ & 3.145 & 2.093 \\
100BI & $31.8 \pm 0.7$ & $25.40 \pm 0.8$ & 3.335 & 1.873 \\
5BU & $31.26 \pm 0.9$ & $30.79 \pm 1.1$ & 2.514 & 1.326 \\
25BU & $29.88 \pm 1.8$ & $30.65 \pm 0.8$ & 3.486 & 1.704 \\
50BU & $29.18 \pm 1.7$ & $31.08 \pm 1.3$ & 3.791 & 1.751 \\
100BU & $30.61 \pm 0.5$ & $31.23 \pm 1.7$ & 3.739 & 2.514 \\
\hline
\end{tabular}

The same Cr evolution is observed for $\mathrm{Ni}$ for the mud effect, cumulative effect and aftereffect. During the second crop, we also observed Ni increases from $5 \mathrm{t} / \mathrm{ha}$, regardless of the type of sludge (Fig. 4). This is quite normal given the quality of the two types of sludge spread including the very high load of industrial sludge in $\mathrm{Cd}, \mathrm{Cr}$, Ni and $\mathrm{P}$.

For zinc (Fig. 5), the only difference with the elements previously reviewed is the rear effect which is slightly less important than the first spread for both types of sludge. This could be explained by the high Zn mobility, which would probably have migrated laterally, or at depth which has blurred the after effect.

The Co contents increase significantly in the seeds (Fig. 6) with the contribution of 5 t/ha of urban sludge and remain constant whatever the year of the application whereas for the industrial sludge the Co levels increase significantly from the 25t/ha dose. All effects (direct, cumulative and aftereffect) are very close. The Co contents are higher in the presence of $100 \mathrm{t} / \mathrm{ha}$ of sludge (Fig. 6).
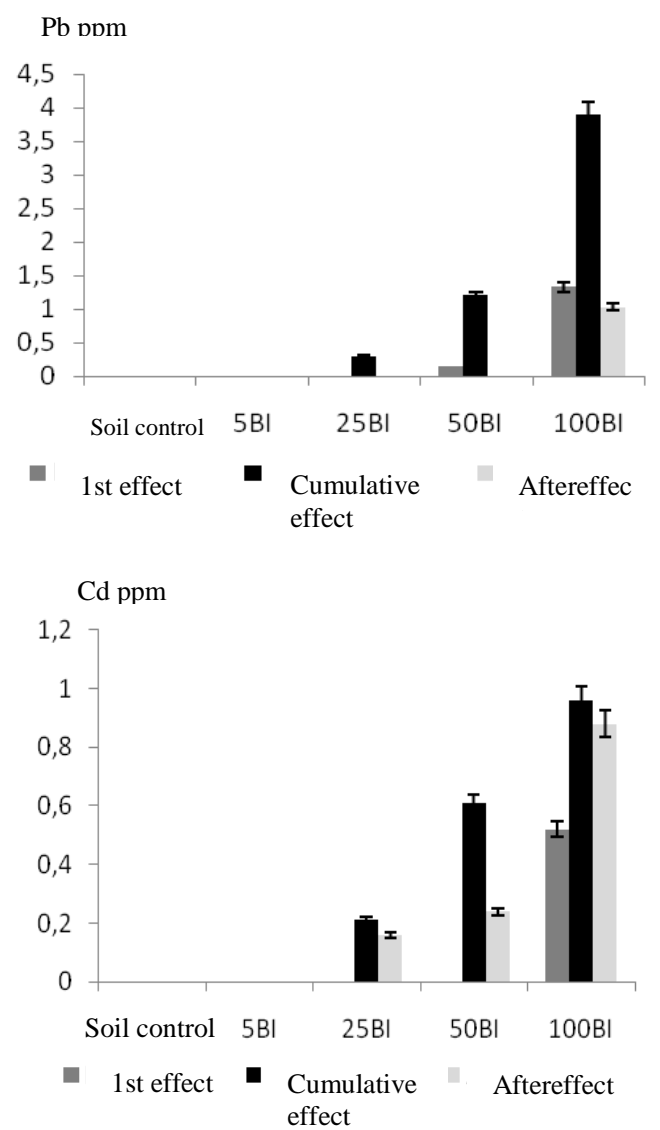

Fig. 3: $\mathrm{Cd}$ and $\mathrm{Pb}$ content variation in rapeseeds grown in the presence of increasing doses of urban and industrial sludge in the first and second year of application.

\subsection{Evolution of heavy metal contents in rapeseed oil}

Analysis of heavy metal data in rapeseed oil (Table 5) shows that all trace metals are present in the oil. Nevertheless, some modifications have been noted.

For urban sludge, no significant difference in 
heavy metal concentrations was observed with the addition of different doses, even after two years of application. On the other hand, we detected differences with the contribution of

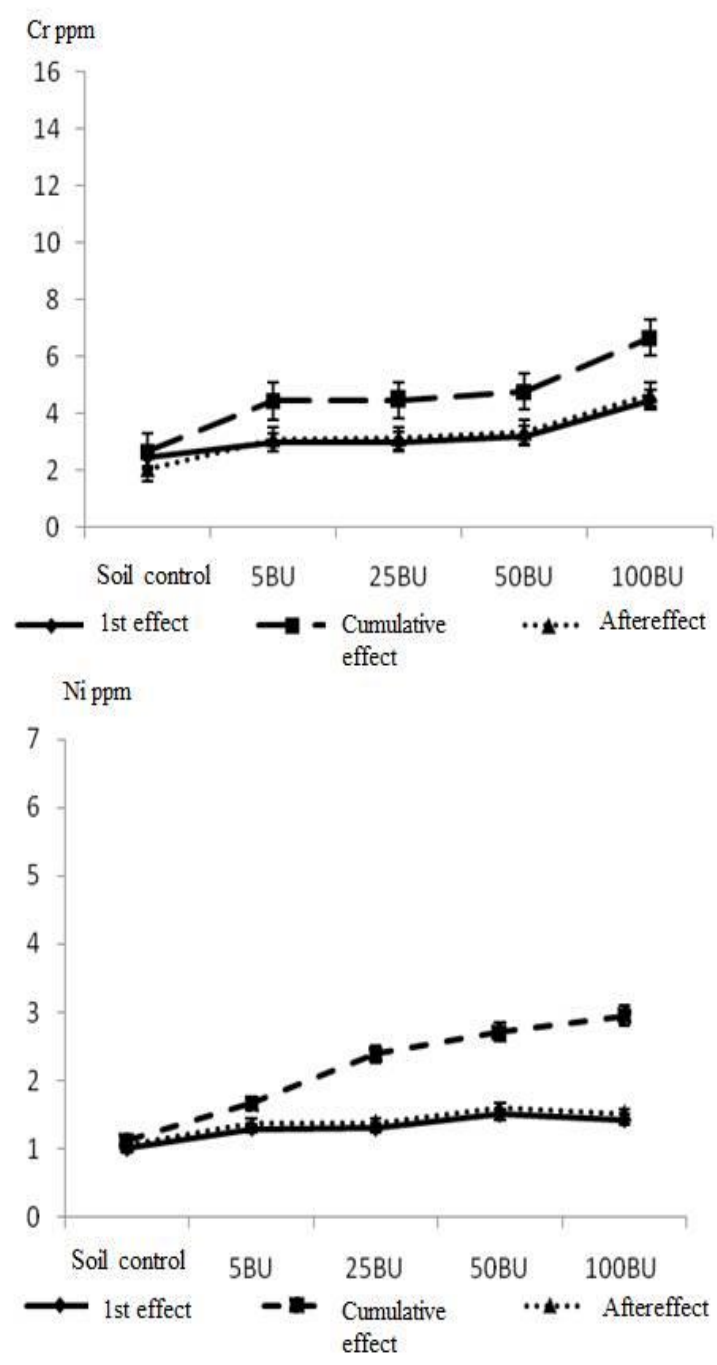

industrial sludge loaded with metallic trace elements.

We have observed increases in most heavy metals especially for high doses. The Cd levels

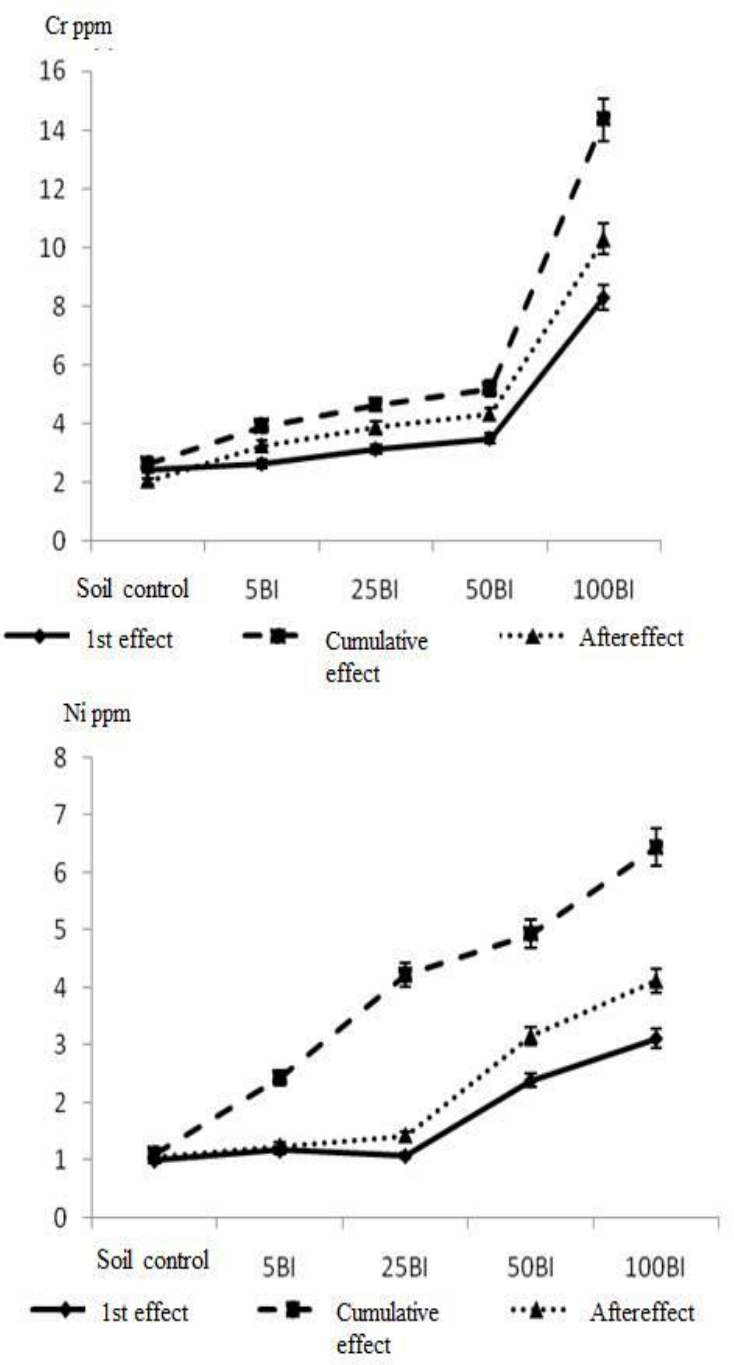

Fig. 4: $\mathrm{Cr}$ and Ni content variation in rapeseeds grown in the presence of increasing doses of urban and industrial sludge in the first and second year of application.

increase significantly with the addition of 100t/ha of industrial sludge, from $1.1 \mathrm{ppb}$ (soil control) to $7.3 \mathrm{ppb}$ during the first year and reach $25 \mathrm{ppb}$ following cumulative intake. During this 2nd year, the sludge effect was observed at $25 \mathrm{t} / \mathrm{ha}$. The $\mathrm{Pb}$ and $\mathrm{Cr}$ contents increase is mostly visible at $100 \mathrm{t} / \mathrm{ha}$. These increases become more important in the second year when the $100 \mathrm{t} / \mathrm{ha}$ dose levels are 3 to 10 times higher than the soil control. For nickel, grades are higher compared to the control when 50t/ha of industrial sludge is applied to both applications. Regarding $\mathrm{Cu}, \mathrm{Zn}$ and Cot no effect doses or sludge types were noted.

\section{DISCUSSION}

Intensification of human activities, especially industrial and agricultural activities, have contributed in recent decades to the contamination of agroecosystems by heavy metals (Rascio et al., 1993). The agricultural valorization of the waste sludge can be a source of pollution in the sense that they can contain toxic compounds (Chaney et al., 1987), in particular the metallic trace elements $(\mathrm{Pb}, \mathrm{Cd}$, $\mathrm{Ni}, \mathrm{Cr}$ ) whose presence constitutes an obstacle to their use (Gupta \& Gupta, 1998 ; Järup et al., 
1998 ; McLaughlin et al., 1998). This sludge is rich in nutrients and is a significant source of nitrogen, phosphorus and micronutrients that must be used to save fertilizer and provide environmentally beneficial sludge removal (Brofas et al., 2000; Kosobuki et al., 2003; Rejeb et al., 2003).

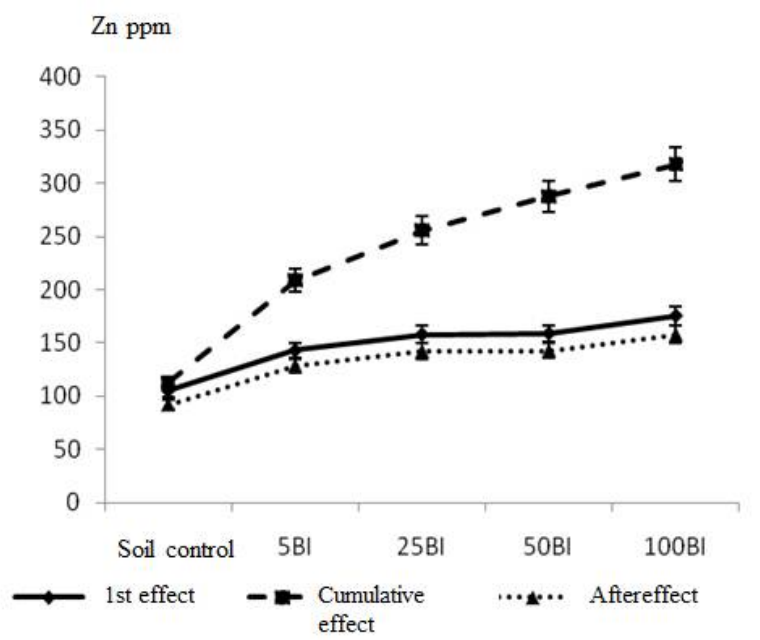

Fig. 5: Variation of zinc accumulation in rapeseeds grown in the presence of increasing doses of urban and industrial sludge in the first and second year of application.

Table 5: Evolution of metal trace element contents (ppb) in rapeseed oil during the first and second year of application. BU: Urban sewage sludge, BI: Industrial sewage sludge and T: soil control.

\begin{tabular}{|c|c|c|c|c|c|c|c|c|c|c|}
\hline \multirow{2}{*}{\multicolumn{2}{|c|}{ Spreading }} & \multirow{3}{*}{$\frac{\mathrm{T}}{0.8}$} & \multicolumn{4}{|c|}{ Urban sludge $\mathrm{t} / \mathrm{ha}$} & \multicolumn{4}{|c|}{ Industrial sludge $\mathrm{t} / \mathrm{ha}$} \\
\hline & & & 5 & 25 & 50 & 100 & 5 & 25 & 50 & 100 \\
\hline \multirow{2}{*}{$\mathrm{Cd}$} & $1^{\text {st }}$ & & 0.7 & 0.9 & 0.7 & 0.9 & 1.0 & 0.7 & 1.1 & 7.3 \\
\hline & $2^{\text {nd }}$ & 0.7 & 0.8 & 0.6 & 0.8 & 0.6 & 0.6 & 2.1 & 8.0 & 25.0 \\
\hline \multirow[b]{2}{*}{$\mathrm{Cr}$} & $1^{\text {st }}$ & 0.6 & 0.5 & 0.6 & 0.5 & 0.5 & 0.7 & 0.4 & 1.6 & 1.0 \\
\hline & $2^{\text {nd }}$ & 0.5 & 0.4 & 0.6 & 0.7 & 0.7 & 0.4 & 0.8 & 1.0 & 5.1 \\
\hline \multirow[b]{2}{*}{$\mathrm{Pb}$} & $1^{\mathrm{st}}$ & 1.6 & 1.7 & 1.6 & 1.5 & 1.5 & 1.5 & 1.6 & 2.1 & 3.2 \\
\hline & $2^{\text {nd }}$ & 1.6 & 1.4 & 1.7 & 1.6 & 1.7 & 1.6 & 1.7 & 1.5 & 5.2 \\
\hline \multirow{2}{*}{$\mathrm{Ni}$} & $1^{\text {st }}$ & 4.3 & 4.7 & 4.2 & 5.2 & 4.7 & 4.2 & 3.7 & 5.1 & 4.2 \\
\hline & $2^{\text {nd }}$ & 4.1 & 4.9 & 5.1 & 4.2 & 5.1 & 3.9 & 4.3 & 5.0 & 5.2 \\
\hline \multirow[b]{2}{*}{$\mathrm{Zn}$} & $1^{\text {st }}$ & 33.4 & 32.1 & 33.5 & 34.1 & 37.4 & 33.2 & 31.0 & 32.0 & 36.0 \\
\hline & $2^{\text {nd }}$ & 30.0 & 30.0 & 32.9 & 37.4 & 38.4 & 33.0 & 41.0 & 33.0 & 32.0 \\
\hline \multirow{2}{*}{ Co } & $1^{\mathrm{st}}$ & 1.1 & 1.0 & 1.2 & 1.3 & 1.0 & 1.1 & 1.0 & 1.1 & 1.0 \\
\hline & $2^{\text {nd }}$ & 1.0 & 1.0 & 1.0 & 1.0 & 1.0 & 1.0 & 1.5 & 1.0 & 1.2 \\
\hline \multirow[b]{2}{*}{$\mathrm{Cu}$} & $1^{\mathrm{st}}$ & 10.4 & 10.9 & 11.0 & 11.6 & 13.0 & 10.0 & 11.9 & 12.6 & 11.6 \\
\hline & $2^{\text {nd }}$ & 9.5 & 9.0 & 10.6 & 10.0 & 11.0 & 10.6 & 10.4 & 10.6 & 12.1 \\
\hline
\end{tabular}

In this perspective and to contribute to the valorization of sludge, several studies have been carried out. The present work on an open-field rape crop aims to study the effects of different types and doses of sewage sludge on seed yield, seed chemistry and rapeseed oil quality.

During the first and second spreading's, the grain yield increased significantly following the application of urban sewage sludge. The increase in biomass and grain yield has been reported by several authors (Christodoulakis \& Margaris, 1996; Singh \& Agrawal, 2008; Togay, 2008). This beneficial effect can be related to a continuous release of nitrogen and phosphorus sludge. We also found that industrial sludge improves production but in a less important way than urban sludge. This may be due to a depressive effect relating to the heavy load of industrial sludge including $\mathrm{Cd}, \mathrm{Cr}, \mathrm{Ni}$ and $\mathrm{Pb}$. 
At the same time, industrial sludge caused a decrease in the weight of thousand seeds following the second intake from the 50t / ha dose. This has been accompanied by a decrease in oil production. The metal load of this sludge can be the cause of this disturbance. Ben Youssef et al. (2004) showed that the oil content shows a decrease proportional to the metal dose.

The application of industrial sludge also induces increases in metal contents in rapeseeds, while for urban sludge, the modifications are attenuated.

The typical effect of sludge is clear. For both types of sludge, the dose effect is visible. The highest levels are recorded with high doses including 100t/ha. For industrial sludge, the levels obtained at this dose exceed the authorized limits for cadmium, chromium, copper and zinc (Darracq et al., 2004). Amin \& Sherif (2001) found the same result where lead, cadmium, nickel and chromium concentrations of bean seed due to sludge application were generally higher than normal values.

The analysis of the fatty acid composition of total lipids shows an increase in the percentage of oleic acid (18: 1) at the expense of linoleic (18: 2) and linolenic (18:3) acids in the presence of industrial sludge. From a nutritional standpoint, these modifications do not seem to call into question the quality of the oil despite the drop in its yield. According to Darracq et al., (2004) after the refining stage, no risk to human health could be identified with respect to rapeseed oil as it will have decreased levels of heavy metals. On the other hand, increasing the level of 18: 1 acid at the expense of linoleic and linolenic acids can be explained by a metalinduced alteration of the process of sequential desaturation of 18-carbon fatty acids.
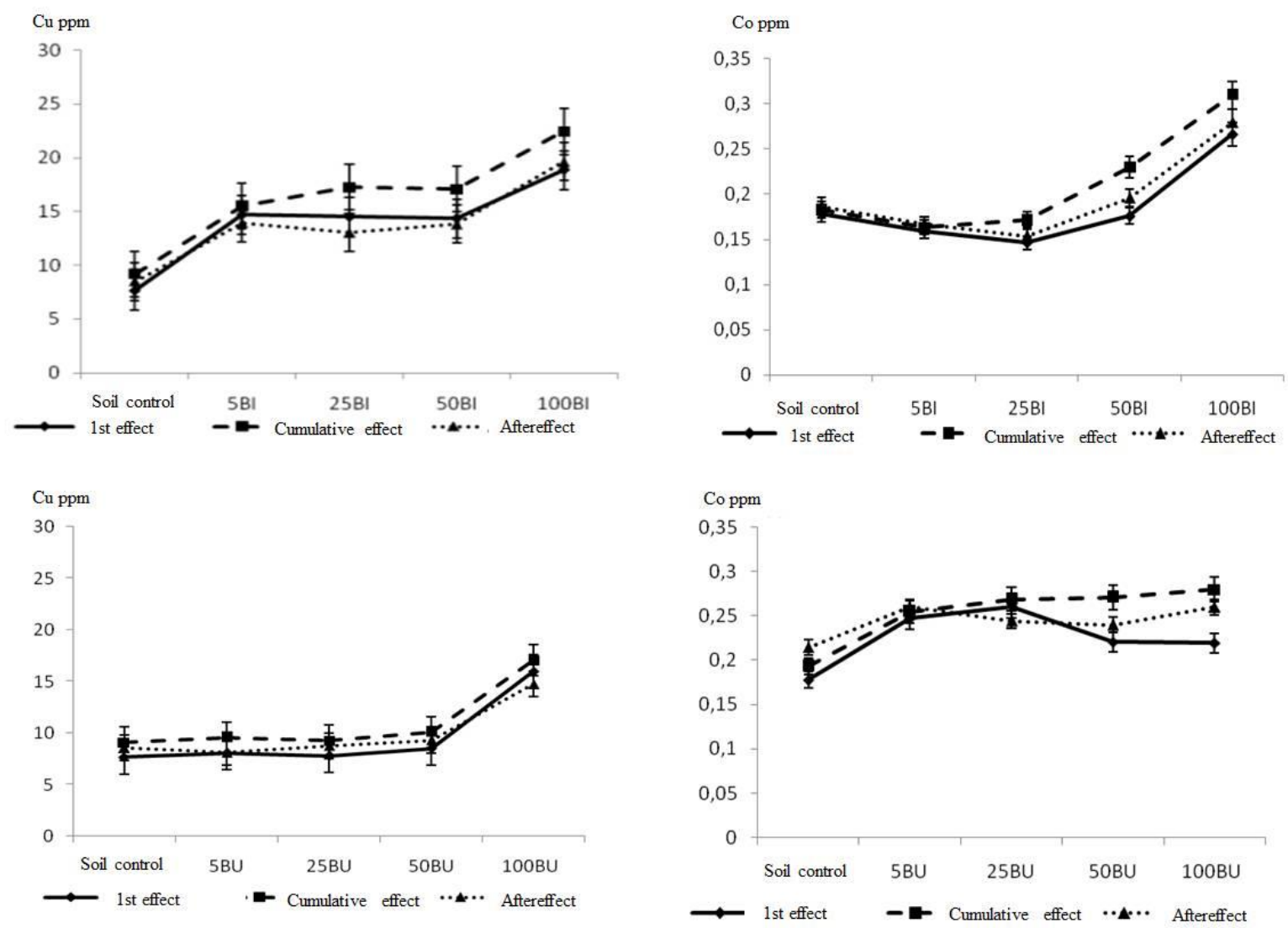

Fig.6: $\mathrm{Co}$ and $\mathrm{Cu}$ content variation in rapeseeds grown in the presence of increasing doses of urban and industrial sludge in the first and second year of application. 


\section{ACKNOWLEDGMENTS}

This work was supported by the National Institute for Rural Engineering research, Water and Forestry, Tunis and Ecole Nationale Supérieure des Mines de Saint Etienne, France.

\section{REFERENCES}

Adriano, D.C., 2001. Bioavailability and Risks of Metals. Trace Metals in Terrestrial Environments: Biogeochemistry. SpringerVerlag, New york, Second ed., 866p.

Alkorta, I., Hernandez-Allica, J., Becerril, J.M., Amezaga, I., Albizu, I., \& Garbisu,C., 2004. Recent findings on the phytoremediation of soils contaminated with environmentally toxic heavy metals and metalloids such as zinc, cadmium, lead and arsenic. Environ. Sci. Biotechnol., 3: 71-90.

Amin, A.W., \& Sherif, F.K., 2001. Heavy metals in maize as affected by sewage sludge application: Morphological characters and yield. Pakistan Journal of Biological Sciences, 4: 1451-1455.

Angelova, V., Ivanova, R., Todorov, G., \& Ivanovi, K., 2008. Heavy metal uptake by rapeseed. Communications in Soil Science and Plant Analysis, 39: 344-357.

Ashworth, D.J., \& Alloway, B.J., 2000. Soil mobility of sewage sludge-derived dissolved organic matter, copper, nickel and zinc. Environmental pollution, 127 : 137-144.

Ben Salah, H., Jouhri, A. \& Marzouk, B., 2000. Effet de la date de semis sur certaines composantes $d u$ rendement et sur la durée du cycle végétatif chez deux variétés de colza de printemps (Brassica napus L.) en Tunisie. Annales de l'INRAT, $73:$ 211-221.

Ben youssef, N. Taammli,W. Ben Temime,S. Daoud, D. Zakrouk, M. \& Ghorbel, M. H., 2004. Cadmium induced changes in growth and seed storage lipids of rape (Brassica napus L.), Rivista Italiana delle Sostanze Grasse, 81: 364-370.

Brofas, G., Michopoulas, P. \& Alifragis, D., 2000. Sewage sludge as an amendment for calcareous bauxite mine spoils reclamation. $\mathrm{J}$. Environ. Qual., 29 : 811-816.

Cecchi G., S. Biasini \& Castano, J., 1985.
Méthanolyse rapide des huiles en solvant. Corps Gras, 4 : pp. 163-164.

Chaney, R.L., Bruins, R.J.F., Baker, D.E., Korcak, R.F., Smith, J.E. \& Cole, D., 1987. Transfer of sludge applied trace elements to the food chain. Land Application of Sludge-Food Chain Implications. Page A.L., Logan T.J., Ryan J.A. eds., Lewis Publishers, Chelsea, MI, pp. 67-99.

Christodoulakis, N.S. \& Margaris, N.S., 1996. Growth of corn (Zea mays) and sunflower (Helianthus annuus) plants is affected by water and sludge from a sewage treatment plant. Bull. Enviro. Contam. Toxical., 57: 300-306.

Darracq S., Bernhard-Bitaud C., Bourrie B., Evrard J. \& Burghart P., 2004. Heavy metals transfer from soil to rapeseed oil. Sustainable Organic Waste Management for Enviromental Protection and Food Safety, 63p.

Gupta, U.C., \& Gupta, S.C., 1998. Trace element toxicity relationships to crop production and livestock and human health. Implications for management. Commun. Soil Sci. Plant Anal., 29: 1491-1522.

Harwood, H.J., 1984. Oleochemicals as a fuel: Mechanical and economic feasability, J. Am.Oil Chem.Soc., 61: 315-324.

James,A.T. \& Martin, A.J.P., 1952. Gas liquid partition chromatography: the separation and microestimation of volatile fatty acids from formic acid to dodecanoic acid. J.Biol.Chem., 50: 679-690.

Järup, L., Berglund, M., Elinder, C.G., Nordberg, G. \& Vahter M., 1998. Health effects of cadmium. The literature and a risk estimate. Scand. J. Work Environ. Health, 1: 24, 1-52.

Kalra,Y.P. \& Maynard, D.G., 1991. Methods for Forest Soil and Plant Analysis. Information Report NOR-X-319, Forestry Canada, Northwest Region, Northern Forestry Center, $116 \mathrm{p}$.

Kchaou R., Khelil M.N., Gharbi F., Rejeb S., Henchi B., Hernandez T. \& Destain J.P., 2010. Isotopic evaluations of dynamic and plant uptake of $N$ in soil amended with $15 N$ labelled sewage sludge. Polish J. of Environ. Stud., 19: 2, 363-370.

Kosobucki, P., Chmarzyeski,A. \& Buszewski, B., 2000. Sewage Sludge Composting. Polish Journal of Environmental Studies, 9: 243-248. 
Leonardis DA, Macciola V, \& Felice DM., 2000. Copper and iron determination in edible vegetable oils by graphite furnace atomic absorption spectrometry after extraction with diluted nitric acid. Int. J. Food Sci. Technol., 35: 371-375.

Marichiol, L., Asooolari, S., Sacco, P., \& Zerbi, G., 2004. Phytoextraction of Heavy Metals by Canola (Brassica napus) and Radish (Raphanus sativus) grown on multicontaminated soil. Environmental Pollution, 132 : 21-27.

Marichiol, L., Asooolari, S., Sacco, P., \& Zerbi, G., 2004. Phytoextraction of Heavy Metals by Canola (Brassica napus) and Radish (Raphanus sativus) grown on multicontaminated soil. Environmental Pollution, 132: 21-27.

McGrath, S.P. \& Cunliffe, C.H., 1985. A simplified method for the extraction of the metals $\mathrm{Fe}, \mathrm{Zn}$, $\mathrm{Cu}, \mathrm{Ni}, \mathrm{Pb}, \mathrm{Cr}, \mathrm{Co}$ and $\mathrm{Mn}$ from soils and sewage sludges. J. Sci. Food Agriculture, vol. 36, 794-798.

McLaughlin, M.J., Parker, D.R., \& Clarke, J.M., 1998. Metals and microntrients - food safety issues. Field crops Res., 60: 143-163.

Pehlivana, E., Arslanb G., Godec F., Altuna T., \& Musa Özcand, M., 2008. Determination of some inorganic metals in edible vegetable oils by inductively coupled plasma atomic emission spectroscopy (ICP-AES). GRASAS Y ACEITES, 59: 239-244.

Rascio, N., Dallavecchia, F., Feretti, M., Merlo, L.,
\& Ghisi, R., 1993. Some effects of cadmium on maize plants. Arch. Environ. Contam. Toxicol., 25: 244-249

Rejeb S., Khelil M.N., Gharbi F. \& Ghorbal M.H., 2003. Effet des boues urbaines sur la production de la pomme de terre. Cahiers Agricultures, 12: 39-42.

Richards, B.K., Steenhuis, T.S., Pevverly, J.H. \& Mc Bride, M.B., 1998. Metal mobility at an old, heavily loaded sludge application site. Env. Poll., 89: 365-377.

Salt, D., Blaylock,M., Kumar,M., Dushenkov,N., Ensley,N., Chert, D. \& Raskin, I., 1995. Phytoremediation: A novel strategy for the removal of toxic metals from environment using plants. Biotechnology, 13: 468-474.

Singh R.P. \& Agrawal M., 2008. Potential benefits and risks of land application of sewage sludge. Waste Management, 28: 2, 347-358.

Szmigielski R., Surratt J. D., Vermeylen R., Szmigielska K., Kroll J. H. Ng, N. L., Murphy S. M., Sorooshian A., Seinfeld J. H. \& Claeys, M., 2008. Characterization of 2methylglyceric acid oligomers in secondary organic aerosol formed from the photooxidation of isoprene using trimethylsilylation and gas chromatography/ion trap mass spectrometry. J. Mass Spectrom., 42, 101-116.

Togay, N., 2008. Effects of municipal sewage sludge doses on the yield, some yield components and heavy metal concentration of dry bean (Phaseolus vulgaris L.). African Journal of Biotechnology, 7: 3026-3030. 